\title{
USP9X wt Allele
}

National Cancer Institute

\section{Source}

National Cancer Institute. USP9X wt Allele. NCI Thesaurus. Code C101575.

Human USP9X wild-type allele is located in the vicinity of Xp11.4 and is approximately 151

$\mathrm{kb}$ in length. This allele, which encodes probable ubiquitin carboxyl-terminal hydrolase

FAF-X protein, is involved in the modulation of protein ubiquitination. 